\title{
Chapter 5 \\ Baltic Crossings: Soviet Housing Estates and Dreams of Forest-Suburbs
}

\author{
Laura Berger, Sampo Ruoppila and Kristo Vesikansa
}

\begin{abstract}
Finland and Estonia had unusually close connections for a Western and a Soviet state following the Khrushchëv Thaw. This chapter addresses the question of how Finnish architecture and planning influenced the development of multifamily housing, including large housing estates, in Soviet Estonia. The chapter shows how information on architecture and planning was exchanged through travel, professional publications, architecture exhibitions and personal contacts. However, inspiration drawn from Finnish examples could influence Soviet Estonian multifamily housing only selectively. The influences, which mainly refer to Finnish modernism from the 1950s and the 1960s, can be identified solely in individually designed and constructed housing projects, which offered more flexibility and room for individual architects to express their visions. Such projects could be developed, for instance, by collective farm construction companies (KEK), not as large state-led projects. Soviet planners borrowed, in many ways, planning ideas from the West, for example, the principle of the mikrorayon, which was applied in the large housing estates. To Estonians, it was particularly the Finnish concept of the 'forest-suburb' that came to be idealised. The development of large housing estates was nonetheless dictated by the Soviet state bureaucracy and extensive use of mass construction technology, especially standardised precast buildings, created a monotonous built environment. Yet some Finnish influence can be recognised in Tallinn's first large housing estate's shopping and service centres, designed and built as separate projects.
\end{abstract}

Keywords Architectural influences - Modernism - Multifamily housing • Finland · Estonia - Soviet Union

\footnotetext{
L. Berger $(\bowtie) \cdot$ K. Vesikansa

Department of Architecture, Aalto University, Helsinki, Finland

e-mail: laura.berger@aalto.fi

K. Vesikansa

e-mail: kristo.vesikansa@ aalto.fi

S. Ruoppila

Department of Social Research, University of Turku, Turku, Finland

e-mail: sampo.ruoppila@utu.fi

(C) The Author(s) 2019

D. B. Hess and T. Tammaru (eds.), Housing Estates in the Baltic Countries,

The Urban Book Series, https://doi.org/10.1007/978-3-030-23392-1_5
} 


\subsection{Introduction}

This chapter addresses the question of how Finnish architecture and planning influenced multifamily housing, including housing estates, in Soviet Estonia. The relationship between the two countries could be described as a 'hinge-point' of architectural influences between a 'Western' and a 'socialist' country during the Soviet era (see Kalm 2002a; Hallas-Murula 2006; Metspalu and Hess 2018). The connection can be partly explained by close cultural and linguistic ties and partly by Finland's ambiguous political status in between Western powers and the Soviet Union. Finnish architecture had influence in Estonia since nation building strengthened in both countries at the turn of the twentieth century. At the time, many known Finnish architects, such as Eliel Saarinen and Armas Lindgren, designed notable buildings in Estonia, and Saarinen won the competition for Tallinn's first general plan in 1913. During the interwar period, international modernism, referred to as functionalism in Finland and Estonia, was popular and played a significant role in developing architectural identity in both countries. World War II interrupted the architectural exchange. Unlike the Baltic states, Finland retained its independence after the war, but was obliged to sign the Agreement of Friendship, Cooperation and Mutual Assistance with the Soviet Union, lasting from 1948 to 1992 . For Finns, the collaborative policy of friendship was a distinct strategy to solve challenging security problems: to accommodate the interests of a big and sometimes threatening neighbour to a certain extent, in order to maintain peace and remain sovereign (Forsberg and Pesu 2016). One consequence of this collaborative policy of friendship was that Finland represented a less antagonistic, nearby territory for the Soviet Union. For Estonians, it provided an important corridor of interaction and exchange with a 'Western' country, even though under restrictive surveillance by the Soviet Union.

To answer our main question on Finnish influences on modernist multifamily housing in Soviet Estonia, we outline three sub-themes: the transfer of architectural and planning information; the special interests of Estonians; and the Finnish influence on the development of multifamily housing in Soviet Estonia. We begin by setting the international context and conclude by discussing the limited space of architectural expression in Soviet Estonia, including what it meant for developing housing estates.

This chapter draws on various types of literatures, such as histories of architecture, planning and construction technology in the Soviet Union, Finland and Soviet Estonia. It brings together topics that have tended to remain separately discussed (e.g. Ritter et al. 2012; Ward 2012; Meuser and Zadorin 2015), regardless of the inherent relatedness, concerning mass housing in particular. Our reading has benefitted greatly from Estonian studies on architectural and planning history (Kalm 2002a; Ojari 2000, 2004a; Hallas-Murula 2006). We have also used selected first-hand materials such as the Finnish Architectural Review, the Estonian Ehitus ja arhitektuur and epoch exhibition catalogues from the Museum of Finnish Architecture (MFA). In addition to the literary sources, we interviewed two Finnish 
architects, Juhani Pallasmaa (born 1936) and Markku Komonen (born 1945), who were among the focal persons networking with Soviet Estonian architects. From Estonia, we consulted the architectural historians Mart Kalm (born 1961) and Triin Ojari (born 1974).

\subsection{Addressing Persistent Housing Demand}

The lack of sufficient and adequate housing was a persistent problem in industrialising and urbanising Europe since the second half of the nineteenth century. While large-scale social housing construction had begun in certain large cities, such as Berlin, Vienna and Amsterdam, after World War I, the housing shortage remained an extensive problem. The situation was worsened by the destruction of World War II. The collapse in construction and residential overcrowding further deepened with the post-war 'baby boom'. Consequently, by the 1950s, meeting housing needs and improving dwelling conditions was high on governmental agendas throughout Europe (Wassenberg et al. 2004; Hall et al. 2006).

In the search for models of healthy urban and housing environments, a particularly influential planning concept was the 'Garden City' (1898), coined by Ebenezer Howard, proposing new developments outside the overcrowded cities. In practice, this and other similar ideas led to increasing development of garden suburbs. Nonetheless, it was the interwar period's radical modernist ideas, debated by the influential members of the Congrès Internationaux d'Architecture Moderne (CIAM), that provided longstanding concepts of what a future city would look like (e.g. Mumford 2000). The free-standing high-rise blocks and strictly delineated separation of land uses (dwelling, work, recreation and transportation) were however implemented on a large scale only after World War II (Wassenberg et al. 2004; Hall et al. 2006). Another influential concept was 'the neighbourhood unit', a residential development area with designated services. This was first introduced by the American planner Clarence Perry in 1929 and spread widely after its adoption in the seminal County of London Plan by Forshaw and Abercrombie in 1943 (e.g. Hurme 1991, 19-39). Last but not least, the development of new construction materials, prefabrication and standardisation played a significant role in the introduction of a novel urban morphology all around Europe (e.g. Hankonen 1994; Meuser and Zadorin 2015).

There were, however, notable differences in how quickly different countries began to implement new ideas. Many West European countries embarked on estate-based housing programmes immediately after World War II, whereas the Eastern Bloc and especially the Soviet Union delayed housing investments further, due to priority being given to industrial development (Hall et al. 2006, 66). This difference can be illustrated by comparing the capitals of Soviet Estonia and Finland. In Tallinn, state-led construction focussed only on the redevelopment of the most badly damaged part of the city centre, one workers' housing district (Pelgurand) and some smaller areas of workers' housing near the heavy industries 
(Ruoppila 2004). Self-construction of single-family houses was also allowed. In Helsinki, in addition to reconstruction following war damage, and distributing lots for the construction of single-family houses, the municipality had initiated the development of several new multifamily housing areas, following the law on state-subsidised housing loans (ARAVA) in 1949. These areas include Ruskeasuo, Maunula, Herttoniemi and parts of Käpylä, all reflecting the Swedish influence on Finnish architecture and planning, regarding the building types, their positioning in the landscape and the overall appearance of the buildings (Hannula and Salonen 2007, 28-31). This touches on the dissemination of architectural influences from the West. Finns followed developments in Swedish architecture and planning closely, and many Finnish architects had been working in Sweden during and after World War II. Swedish planners had adopted the rapidly spreading concept of neighbourhood units from Great Britain and the USA. The early Swedish examples of post-World War II housing developments are the Årsta district in Stockholm (1943-53) and Norra Guldheden in Gothenburg (1944-47) (Hurme 1991, 55-63).

\subsection{From Mikrorayons to Grand Ensembles to Paper Architecture}

The death of Stalin in March 1953 and his replacement by Nikita Khrushchëv brought a major change in urban, social and cultural development in the Soviet Union. The improvement of living standards was raised as a main goal after severe neglect throughout the Stalin years. Increasing the housing supply was a pressing concern, followed by the need to improve production technology and urban planning.

The turning point in Soviet city building was Khrushchëv's almost 2-h-long address titled 'On the wide-scale introduction of industrial method: improving the quality and reducing the cost of construction' given at the All-Union Building Industry Conference in December 1954. Forty $(2012,151)$ describes how a young architect, Georgei Gradov, had daringly written a 100-page letter to Khrushchëv, informing him of the shortcomings of the Soviet construction industry. Consequently, 'on no other occasion has a head of a state delivered such a lengthy and informed speech about concrete', writes Forty (ibid.). Khrushchëv criticised the appreciation of form over function, namely spending state funds on the 'architectural excess' of the decorative Stalinist style. However, he also criticised the constructivist architects of the 1920s and 1930s for prioritising architecture and design. Instead, stated Khrushchëv, mass production, standardisation and new technologies were to set the new guidelines for all construction (Anderson 2015, 216).

Khrushchëv saw an opportunity to learn about and selectively apply Western innovations to improve living standards in the Soviet Union. In housing and planning matters, this meant a growing interest in mainly French mass-production technology, as well as Swedish, Finnish and British planning ideas (Ward 2012, 510). As part of catching up, professional study trips were organised from and to 
the Soviet Union. Soviet planning professionals made a first visit to Britain in 1955 , followed by several return visits, culminating in a tour that the Soviet Union organised for British visitors in 1960 (Ward 2012, 512). Architecture and planning literature was also actively translated into Russian, and Soviet magazines like Arhitektura SSSR introduced projects from foreign countries, including France, Czechoslovakia, Poland, UK and the Nordic countries (Caldenby and Wolodarski 1973, 34-35). Regarding industrial building methods, the Soviet Union commissioned the French firm Raymond Camus et Cie to develop precast concrete factories in Tashkent and Baku in 1958, making the Camus panels available in the USSR (Meuser and Zadorin 2015, 114; Anderson 2015, 221). According to Anderson $(2015,220)$, the organised spreading of Western planning ideas and the adoption of novel technologies enabled the Soviet Union to literally jump-start housing construction.

In 1957, the leadership of the Soviet Union made a remarkable political promise to end the housing shortage within a maximum of twelve years (Smith 2009, 26). Even though that bold promise would fail, by the end of Khrushchëv era, this 'first rank social reform, which gave Soviet citizens the right to expect better housing conditions within the foreseeable future, was well on the way' (ibid., 26). Moreover, in 1961 the communist party declared that by the end of the $1970 \mathrm{~s}$ 'every family, including the newlyweds, will have a comfortable apartment conforming to the requirements of hygiene and cultured living' (ibid., 28). Consequently, state funding for housing construction was increased, and construction further centralised, including a full-scale implementation of the industrialised building methods, such as precast panels. The first experimental mikrorayon (1956-59) had been constructed in Novye Cheremuski in Moscow, and this was chosen as the model unit to be copied all over the Soviet Union (Anderson 2015, 222).

Soviet city building had taken a new direction during the Khrushchëv era, but construction volumes were at a peak during the Brezhnev period (1964-82), transforming the built environment. Between 1960 and 1975, no less than two-thirds of the total population in the Soviet Union was allocated improved housing with district heating (Bater 1980, 97; Beyer 2012, 261). Under Brezhnev, a new generation of prefabricated systems was developed, and standardisation was taken further. Whereas the projects realised during the 1950s and 1960s had been based on type series, each with specific building components, between 1969 and 1972, the Moscow Scientific Research Institute of Experimental Design developed an 'open typification', which allowed building elements to be mass-produced as interchangeable sets of components. 'Open typification' enabled the construction of 9- to 25-storey buildings (Anderson 2015, 254). Such tower blocks, or 'grand ensembles', executed in Moscow and other large cities, were characteristic of the Brezhnev era. By 1991, industrialised housing comprised $75 \%$ of all Soviet housing stock (Meuser 2012, 274).

Mass housing in the Soviet Union was a task for the State, which determined the amount and location of new buildings. Official Design Institutes were responsible for the entire planning process and the State Building Concerns of the construction 
job. Consequently, architects working in the Design Institutes needed to comply largely with the standardised designs (Meuser and Zadorin 2015, 13). Nonetheless, architects had local influence in how the housing estates were shaped (Metspalu and Hess 2018). Moreover, different state agencies, including construction companies of collective farms, could also commission individually designed apartment buildings (Kalm 2012a, 198-201; Caldenby and Wolodarski 1973, 133-136). Architects working for the state were also allowed to do extra projects, typically private houses but occasionally also small apartment blocks (Kalm 2002a, 239, 2004; Metspalu and Hess 2018, 356).

Some architects also produced so-called paper tigers, projects categorically too artistic or whimsical to ever be realised. Towards the end of the Soviet period, this turned into an entire phenomenon referred to as 'paper architecture', as the discontented younger generation of architects took a rebellious stance in pushing the limits between art and architecture, rejecting functional demands, and embracing narrative and expression instead. Such a reflection of new pride in the profession has been considered to anticipate glasnost and perestroika within architecture (Klotz 1988, 7). The beginning of 'paper architecture' has been dated to 1981, when Mikhail Belov and Max Kharitonov, later well-known professionals, won the competition for an exhibition house sponsored by the periodical Japan Architect. 'Paper architecture' has since been described as 'sublimation of despair', an ultimate escape from the harsh realities dictated by the Soviet building industry (Anderson 2015, 286).

\subsection{Crossing the Baltic Sea}

With the Khrushchëv Thaw, the connections between Finland and Estonia were also gradually restored. The first Soviet Association of Architects (Sojuz Arhitektorow SSSR) study trip to Finland, with 14 Estonians among the group, was made in 1957. Estonian architects subsequently visited Finland almost annually (Hallas-Murula 2006, 127). An excursion report published in the Estonian periodical Ehitus ja arhitektuur (Construction and architecture) lists a wide range of contemporary buildings, such as offices, hospitals, university buildings, hotels and various kinds of housing, visited by Estonian architects (Mirov 1965). In addition, some excursions concentrated on specific topics, such as hospitals (Luts and Avarsoo 1967). Ehitus ja arhitektuur reveals that building engineers likewise built relationships and became familiar with contemporary developments in Finland (e.g. Jürisoo and Malmet 1966). According to Mart Kalm, during the Soviet years, architects were required to note international travels in their official curriculum vitae. Based on this information, Kalm has calculated that as many as half of the members of the Estonian Architects' Union visited Finland during the 1960s (Kalm interview).

In addition to travel, architecture periodicals were an important source of information. The Finnish Architectural Review (Arkkitehti) was ordered for the 
Estonian Academy of Sciences library in 1958, and the Swedish Architectural Review (Arkitektur) the following year (Kalm 2002b, 66). Importantly, periodicals provided information and images from the very latest projects. As Finnish modern architecture was highly regarded at the time the connections were re-established, Estonian architects were also able to learn about Finnish architecture from international publications. According to Kalm (2002a, 414), the projects presented especially in Finnish and Danish architecture periodicals played an important role as idealised educational material at the Estonian Academy of Arts, which was the only school of architecture in Soviet Estonia, until the end of the 1970s.

Two Finnish housing estates stand out among those most documented in publications during this era. These are Tapiola (the first stage built 1952-56), which was an early realisation of the neighbourhood unit concept, and Pihlajamäki (195965), where prefabrication was first used on a large scale. It appears that Tapiola (see Fig. 5.1) and Pihlajamäki (see Fig. 5.2), the best-known examples of Finnish 'forest-suburbs', also remained the housing estates that Estonians visited most frequently, even decades after their completion.

Tapiola was developed as a model community in the rapidly growing Helsinki region. The development was initiated, unusually for the time, by large non-governmental organisations (Hurme 1991, 105). Its development was preceded by distribution of an influential anti-urban pamphlet Homes or barracks for our children by von Hertzen (1946), which presented the prevalent Swedish examples Norra Guldheden and Friluftsstaden, as well as American greenbelt cities, as ideals for new housing areas. Moreover, the planner of Tapiola, Otto-Iivari Meurman, had just published his influential book on detailed planning (1947), to be used for decades to come in teaching urban planning in Finland. Meurman's work combined ideas of garden cities, the neighbourhood principle and functional separation, all of which were implemented in Tapiola. Notably, the area pays homage to the Swedish and American exemplars: buildings and curving routes are positioned carefully in the landscape, and the high-quality architecture was realised synchronously with well-designed green areas. The buildings were designed by leading Finnish architects of the time, including Alvar Aalto, Aarne Ervi, Viljo Revell, and Kaija and Heikki Siren. The Tapiola civic centre, designed by Ervi, closely follows ideas promoted by the CIAM after World War II, such as the balance between commercial and public spaces (Lahti 2006, 119-129). The latest construction technology was also utilised: the experimental blocks of flats made of precast panels, designed by Ervi and Revell in 1953-54, were among the first in the country (Hytönen and Seppänen 2009, 36, 212).

The planning of the Pihlajamäki housing estate in northern Helsinki drew much on the ideals and experience of Tapiola, but the ideas of standardisation and prefabrication were developed further, and the architectural expression was more ascetic. The plan was drawn by Olli Kivinen, who had previously worked in Meurman's office. The City of Helsinki, which was the landowner, assigned the development to two construction companies, HAKA and SATO, of which, in particular, the latter used precast panels. In contrast to a variety of housing types in Tapiola, Pihlajamäki has essentially two types of residential buildings: long 

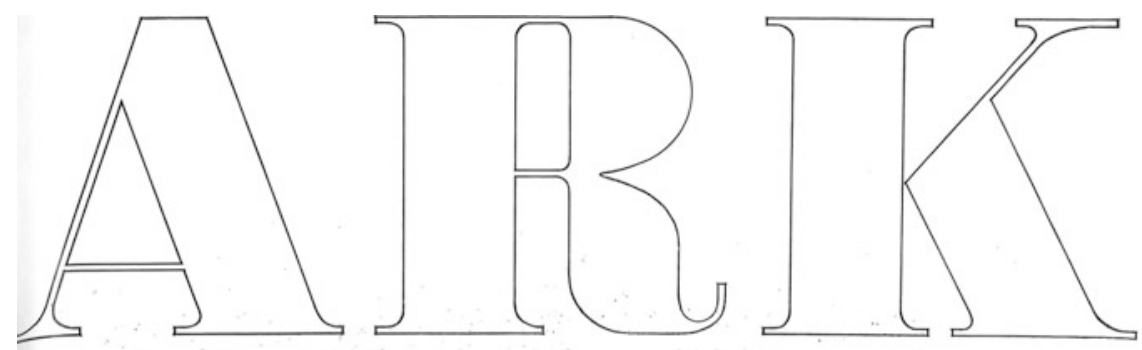

A R K K TEHTI ARKITEKTEN $12 / 1961$

TAPIOLAN KESKUSTA

HAGALUNDS CENTR

TAPIOLA CENTRE

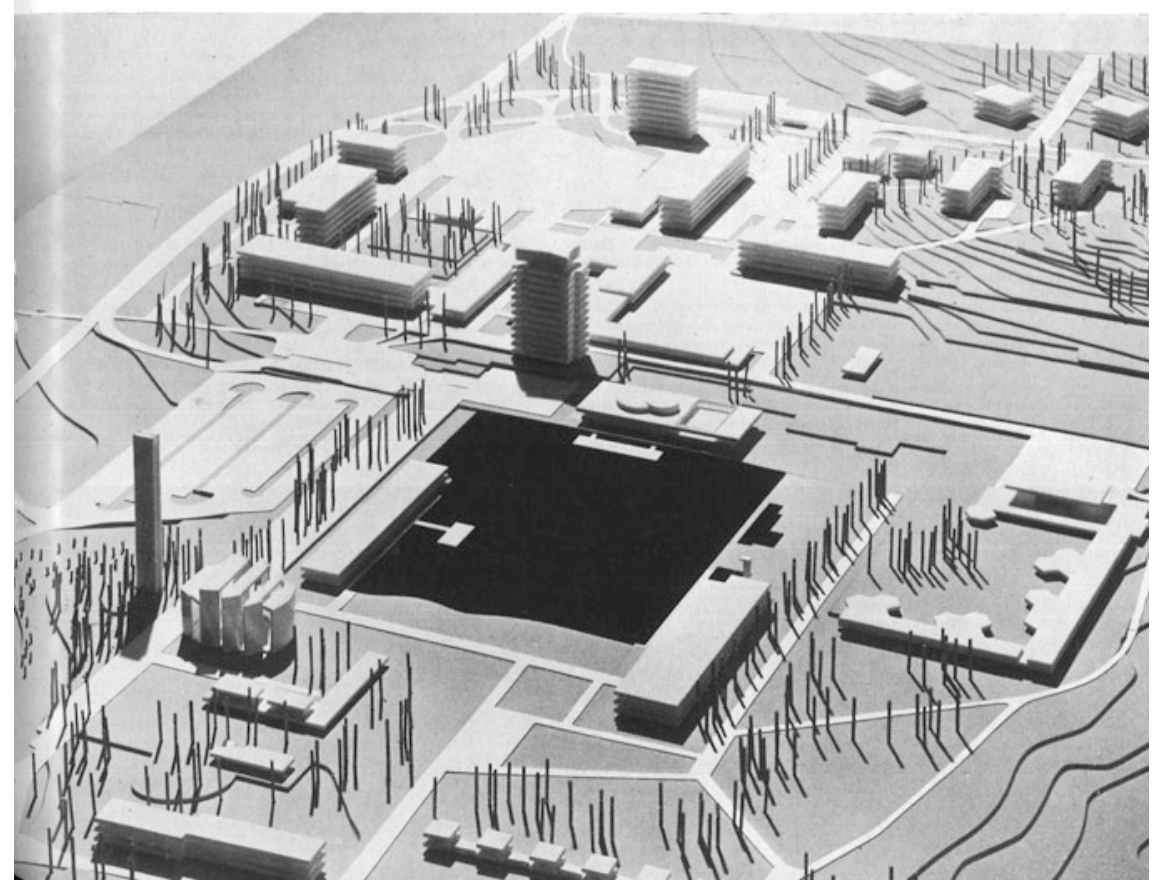

Fig. 5.1 Cover of the Finnish Architectural Review 12/1961 illustrating Tapiola Centre by Aarne Ervi. Source Finnish Architectural Review, used with permission

4-storey buildings following the landscape, and tall tower blocks located on the highest point of the hill. The commercial services are mainly located in the area's own shopping centre (Hurme 1991, 144-163).

As a single work, Tapiola was presumably the most influential piece of Finnish modernism for Estonian architects. Putatively, all Estonian architects travelling to Helsinki from the mid-1950s to the 1970s visited it (Hallas-Murula 2006, 140). 


\section{A R K K I T E II T I A R K I T E K T E N 10-11/1964}

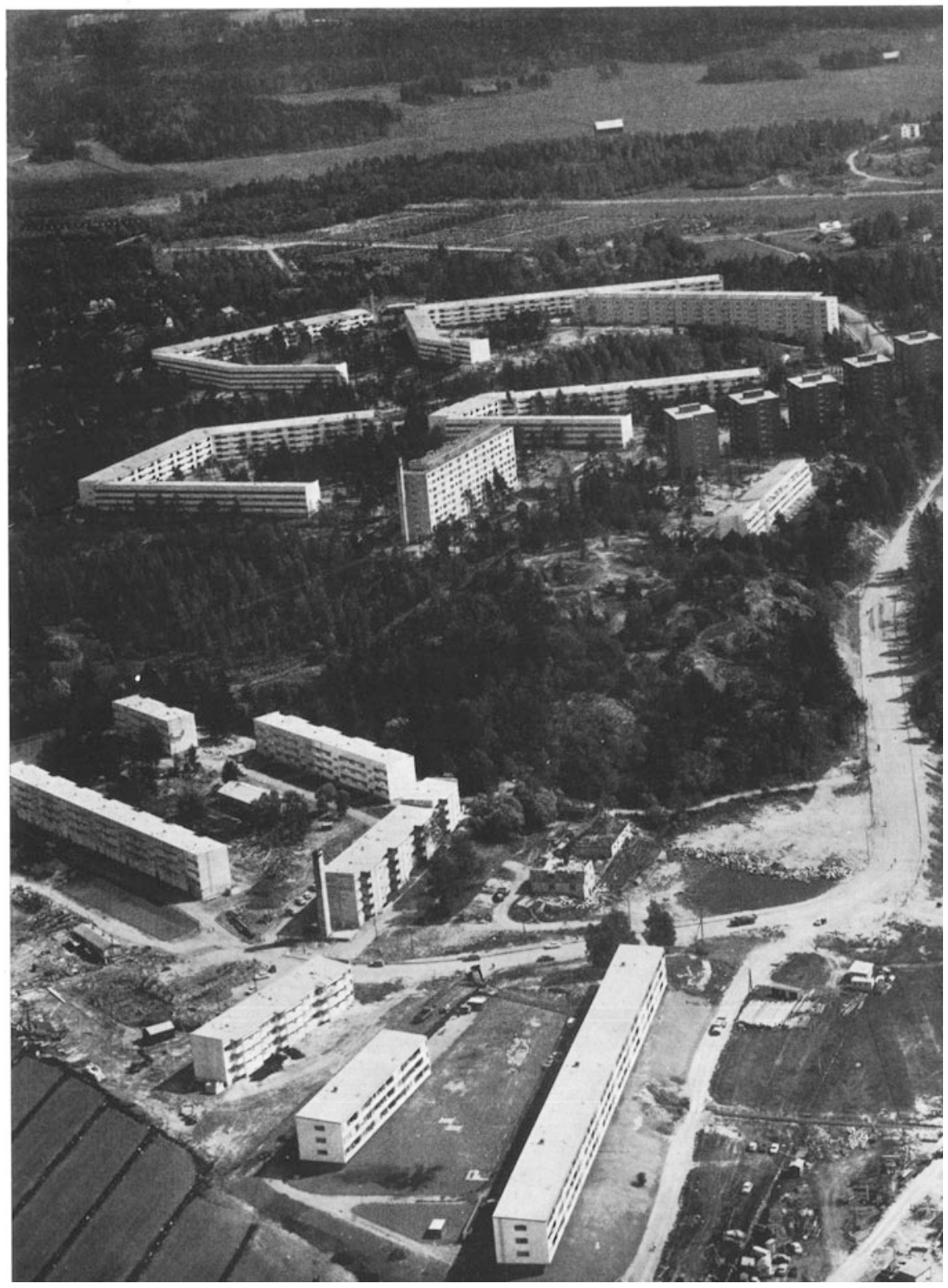

Fig. 5.2 Cover of the Finnish Architectural Review 10-11/1964 illustrating Pihlajamäki estate. Source Finnish Architectural review, used with permission 
In the published excursion reports, Tapiola was described very positively. For instance, Raul-Levroit Kivi (1960) emphasised the variety of building types, how they were freely positioned into the forest, and the relationship between grass fields, decorative plants, hedges, paved pathways, resting places and playgrounds. He also commented on the different types of finishes on the facades, the open balconies and rational kitchens. According to Kivi, characteristics of Finnish building culture were good taste, functionality and perhaps above all, the good quality of construction, which was something architects working in the Soviet Union could only dream about (Kivi 1960, cited in Hallas-Murula 2006, 140-141). Tallinn's chief architect, Dmitri Bruns, paid close attention to the planning; the deliberate contrast between the terraced houses and the towers, and how the streets followed the natural landscape, with no separate pavements (Bruns 1961, cited in Hallas-Murula 2006, 141). Both Hallas-Murula (ibid. 141-143) and Kalm (interview) refer to the connection with nature and the preservation of old trees between the buildings as something specific. This marks a difference in planning traditions between the countries. In Estonia, the idea of 'open planning', or positioning free-standing apartment blocks in an existing landscape, was first introduced in the architectural competition for Tallinn's Mustamäe district in 1958 (Ojari 2000, 55-59). In Finland, taking the landscape into account had been an integral part of planning since the 1930s. An interesting point is that Estonians seemed not to lose interest in Tapiola over time but continued to refer back to it when it was no longer considered topical in Finland. An example is Voldemar Herkel's (1967) article on Finnish single-family and terraced houses, referring mostly to buildings from Tapiola.

The Finnish Association of Architects made its first excursion to Tallinn in 1962. Three years later, a passenger ferry connection between Tallinn and Helsinki was restored, making Finnish visitors a common sight in central Tallinn. According to Ojari $(2004 b, 25)$, the writings and memories of the era illustrate the personal and warm-hearted relationships between Finnish and Estonian architects. ${ }^{1}$ The meetings depended mostly on Finns travelling to Tallinn, because Estonians needed to obtain permission to travel, which was politically controlled and often painstakingly difficult to get (e.g. Pedak 1999). In 1968 Väinö Tamm received a scholarship to study in Finland, and also worked at the office of Erkki and Kirsti Helamaa, reflecting a personal relationship transforming into a work opportunity (Hallas-Murula 2006, 130). This, however, remained a rare example, as the Soviet authorities did not allow close contacts to be established until the years of perestroika and glasnost.

When the Finns visited, they brought over not only much-valued professional journals, but also Finnish weekly magazines, books, and even pencils and sketching paper, which were scarce in Soviet Estonia, Pallasmaa noted in our interview.

\footnotetext{
${ }^{1}$ Among the key persons in keeping the contacts were on the Finnish side, Erkki Helamaa (19242014), Veijo Martikainen (born 1925), Kirmo Mikkola (1934-86), Juhani Pallasmaa (born 1936), and Markku Komonen (born 1945); and on the Estonian side, Edgar Johan Kuusik (1888-1974), Valve Pormeister (1922-2002), Mart Port (1922-2012), Tõnis Vint (born 1942), Leonhard Lapin (born 1947), and Vilen Künnapu (born 1948) (Lapin 1996, 134; Kalm 2002b, 67; Hallas-Murula 2006, 127; Komonen and Pallasmaa interviews).
} 
Most of all, he recalls smuggling art books. Whatever the material was, it was often hidden because of a risk of border control officials confiscating almost anything Western as suspicious (Lapin 1996, 98-100). At the time, foreign contacts were so valuable among Estonians that the Finnish architects likely did not understand that there might have been competition for friendships among their Estonian colleagues (Kalm interview).

Another significant method of passing the information was exhibitions, which typically presented canonised architectural examples, offering an idealised image. Furthermore, these, too, provided a legitimate reason to travel, in their part strengthening the collegial exchange. The first exchanged exhibitions, organised in 1960 and 1961, focused on applied arts and design (Kalm 2002b, 66). In 1966, an exhibition on the restoration of Tallinn's old town was held at the Museum of Finnish Architecture (MFA). As part of the occasion, 13 Estonian architects travelled to Finland and organised a follow-up seminar for students from both cities. The same year, representatives of the Finnish Association of Architects and its standardisation department travelled to Tallinn, bringing with them Finnish building standard catalogues. In 1968, an exhibition focusing on modern Finnish architecture was sent to Tallinn (Hallas-Murula 2006, 129).

The difference in the contents of the exhibitions and to whom they were directed is noteworthy. The exhibitions sent out by MFA aimed to present the best achievements of Finnish architecture, hence focusing on new buildings and individual architects, and often also circulated elsewhere in the Soviet Union, including Leningrad, Moscow and other Baltic republics (Čeferin 2006). In contrast, the architectural exhibitions brought from Soviet Estonia to Finland represented, for a long time, only traditional styles, and were exhibited only in Helsinki. ${ }^{2}$ It was, however, possible to introduce recent Estonian architecture as part of the wider Soviet context. When MFA and the Soviet Association of Architects organised an exhibition of the latest architecture in the Soviet Union (Neuvostoliiton nykyarkkitehtuuria 1973), two Estonian projects were included. These were a commercial centre (Peep Jänes 1963-70) and Tallinn Polytechnic Institute (Uno Tölpus, Henno Seppman and Olga Kontšajeva 1958-71), both located in Mustamäe. All in all, as a form of exchange, exhibitions are illustrative of how contacts between institutions created opportunities for travel, the transmission of professional materials, and the development of personal contacts.

The beginning of the 1980s marked, in many ways, a considerable change in the direction of interests. The new generation of Estonian architects had taken a critical stance with regard to the Soviet system, in particular mass housing, and post-war modernism overall. They also broke away from the ideals of the previous generation, including the tendency to look up to Finnish or Danish architecture (Kalm 2002a, 414). The group emphasised that architecture was art, and many became known as visual artists alongside their architectural profession. Instead of Finnish

\footnotetext{
${ }^{2}$ The lists of exhibitions held at the MFA and circulated internationally can be found at: http:// www.mfa.fi/vaihtuvat-nayttelyt and http://www.mfa.fi/kiertonayttelyt-ulkomailla.
} 
modernism, they drew inspiration from American postmodernism, the Soviet avant-garde of the 1920s, and the interwar Estonian functionalism and cultural heritage. These architects had been virtually excluded from the large state-led projects and had no interest in complying with those rules. However, many of them worked with the design bureau of the collective farms (EKE Projekt), which enabled architecturally more ambitious projects, such as a large cooperative housing complex in Pärnu (Toomas Rein 1972-87) (Kalm 2007, 360-367). The single-family houses had also become an increasingly popular alternative for mass housing since the 1970s (Ruoppila 2004), and therefore homeowners were only too happy to see ambitious designs (Kalm 2012b, 41).

Before the 1980s, the Finnish Architectural Review had not paid much attention to contemporary projects in Soviet Estonia, except for the Tallinn Song Festival Stage (1957-60), an immense suspended canopy (Kotli 1963). The international breakthrough for the new generation, however, received help from the Finns. They became known as the 'Tallinn School' (Kurg 2009), a name coined by Markku Komonen, the editor of the Finnish Architectural Review. In 1980, the periodical published Leonhard Lapin's seminal article presenting the new generation of Estonian architects (Lapin 1980). In 1983, the group organised the exhibition '10 architects from Tallinn', which Komonen imported to Finland the following year. This involved, among other things, Komonen smuggling the exhibition manuscript from Estonia to Finland, as he recalled in an interview. ${ }^{3}$ The exhibition (Komonen 1984) was displayed in Helsinki, Rovaniemi, Kotka, and Jyväskylä in 1984, followed by Riga (1985), Moscow (1986), Kiel (1989), Zurich (1990), and Stockholm (1990) (Hallas-Murula 2006, 178).

A novel tactic of escaping the dull Soviet reality that hampered the realisation of architectural expression was participating in international architectural competitions. To make this possible, the Finns visiting Tallinn were asked not only to import a variety of materials, but also to smuggle the drawings out of the country, and to send the competition entries from Finland. At times, the information reached the ears of the Soviet authorities if the Estonian entries received awards (Lapin 1996, 98-100). One example was the West Coast Gateway competition for a monument to immigrants in Los Angeles (1989). Juhani Pallasmaa was a member of the jury, and he remembers having been utterly dumbfounded upon realising who the architect behind the entry winning the second prize was: 'God damn it, that's Künnapu's work! I recognised it immediately. That was how Künnapu made his breakthrough'.

The Finnish Architectural Review published another two issues on Estonian architecture later in the 1980s (Arkkitehti 4-5/1987 and 7/1989). In addition, another famous competition entry for the Arctic Centre in Rovaniemi, Finland, by Vilen Künnapu, Ain Padrik, and Lennart Meri (then an ethnologist, later president) was published on the cover of the periodical (Arkkitehti 2-3/1984).

\footnotetext{
${ }^{3}$ One architect, Jüri Okas, left the group, and consequently, the name of the exhibition was 'Nine architects from Tallinn'.
} 


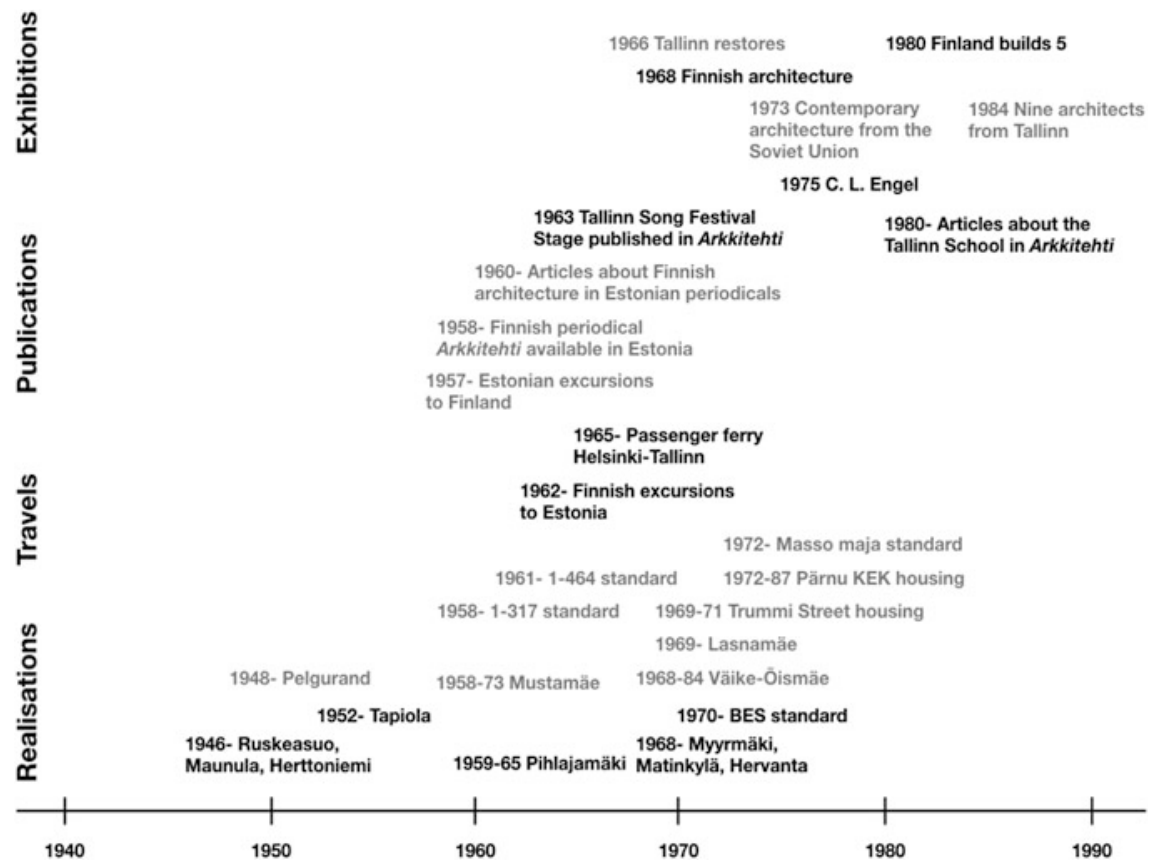

Fig. 5.3 Timeline illustrating architectural exchange and housing development in Finland and Soviet Estonia (Finnish contributions marked in black, Soviet Estonian in grey)

In the context of information exchange, Finnish television, which was increasingly watched in Northern Estonia from the 1960s onwards, is worth mentioning as an important uncensored window to the Western lifestyle and consumption (Høyer et al. 1993, 200), including the changing ideals of the built environment. Finland's role as the closest Western neighbour, the formation of friendships and its overall influence as a nearby reference point also went far beyond architects' circles.

A timeline connecting various points of architectural exchange and housing development in Finland and Estonia is presented in Fig. 5.3.

\subsection{Variations in Standardisation}

In developing multifamily housing, and especially housing estates, standardisation and industrial construction techniques played a crucial role. Nonetheless, due to the political and economic differences between the countries, the standards developed from different premises. In Finland, standardisation was actively promoted by real estate development and construction companies, but also by the Finnish Association of Architects. The state authorities also regarded this development as beneficial for the national economy. The first experimental prefabricated apartment 
blocks were realised in Tapiola in 1954. From the late 1950s, construction companies began to establish their own factories, making it possible to realise entire residential districts, for instance in Pihlajamäki. A next step was the introduction of an open system called BES (betonielementtisysteemi) as a national standard in 1970. This was a joint initiative of the Finnish Ministry of Housing and the concrete industry, in order to speed up housing production. BES enabled components produced by different factories to be used in the same project. BES soon became the dominant system, and the highest peak of housing construction was reached in the mid-1970s (Hankonen 1994, 139-223; Hytönen and Seppänen 2009, 19-133, 208-227). After this, more varied alternatives were developed, but still relying on the same structural principles.

In Estonia, the models of standardised apartment buildings closely followed the Soviet models. The first widely used standard 1-317 was developed by Estonian architects working for the local Design Institute Eesti Projekt (1956-58), following a standardised model outlined in Moscow (Ojari 2004a, 48). This Estonian version of the so-called khrushchëvka had slightly narrower volume than the original model to allow more natural light, which was crucial in the northern setting (Kalm 2002a, 329-331). The khrushchëvka were built extensively over the next decade. In 1961, the Tallinn building company was established to produce precast panels according to the Soviet 1-464 standard, based on the Camus system that had been purchased for the Soviet Union a few years earlier (Kalm 2002a, 342). Most of the Mustamäe and Õismäe housing estates were constructed using the 1-464 standard. By the time Lasnamäe was developed, in the 1980s, several open typification systems had been developed in Moscow and Leningrad, but in Tallinn the production of the precast panels did not change significantly. In the shadow of Soviet standards, Estonian architects attempted to develop more flexible systems, but few of them got built. One exception was a standardised apartment block, which architect Miia Masso managed to get into small-scale production in 1972 (Kalm 2002a, 342). The extensive construction of mass-produced apartment blocks in Tallinn was driven by industrialisation, urbanisation and immigration from the other Soviet republics. By the end of the Soviet period, two-thirds of Tallinn's inhabitants were settled in mass-produced apartment blocks (Ruoppila 2004).

\subsection{Finnish Influences on Estonian Multifamily Housing}

Both Kalm (2002a, 316-326; 353-368; 375-388) and Hallas-Murula (2006, 131173) offer comprehensive analyses of the influence of Finnish architecture on Soviet Estonia. Hallas-Murula considers the influence as predominantly Finnish, Kalm as Scandinavian, yet transmitted through Finland in particular. Drawing on Hallas-Murula and Kalm, at least three different phases of Finnish influence can be recognised: the organic architecture of the late 1950s and the early 1960s; the so-called cornice architecture, which became popular in the mid-1960s; and the neo-functionalism of the 1970s. Organic architecture strove to position buildings in 
the landscape and to use natural materials. Typical of 'cornice architecture' were simplified, horizontal volumes and broad cornices, and neo-functionalism was characterised by abstract, geometric forms. Most of the projects to which Hallas-Murula and Kalm refer are public and semi-public buildings or single-family houses. In other words, smaller scale projects allowing greater architectural freedom in comparison to the standardised solutions that characterised the large housing estates.

Nevertheless, Kalm (2002a) and Hallas-Murula (2006) also refer to certain multifamily housing projects that have drawn on influences from Finnish architecture. The earliest post-war example given by Kalm (2002a, 342) is an experimental apartment block built on Gonsiori Street in central Tallinn (1960), as the Estonian architects aimed to design better-quality standardised solutions for mass housing. According to Kalm (ibid.), the floor plans were based on apartment blocks in the Roihuvuori district in Helsinki, designed by the Finnish architect Esko Korhonen in 1954-60. A tangible inspiration, if not even a copy of Tapiola, has been identified in the type-planned single-family house series IE-1 and RE-1, presented in 1967 (Hallas-Murula 2006, 151). Later multifamily houses inspired by Finnish architectural models include, for instance, Toomas Rein's terraced buildings in Vändra (1969-79) and Pärnu (1972-87). These have been analysed to draw inspiration from Alvar Aalto's works, as well as more generally from 1960s Finnish housing architecture, characterised by strip windows and contrast between white walls and dark window frames (Hallas-Murula 2006, 154-157). Raine Karp's Trummi Street housing complex in Tallinn (1969-71), which consists of a row of terraced houses and three apartment blocks (see Fig. 5.4) developed for Academy of Sciences employees, was inspired by the part of Pihlajamäki designed by Lauri Silvennoinen, as well as Viljo Revell's architecture in general (Kalm 2004).

Regarding Tallinn's large housing estates, the question of Finnish and more widely Western influences is most interesting in the earliest one, Mustamäe (195873), developed when Soviet planning was taking a new direction (see Fig. 5.5). In this case, the Western influences, namely the British and French planning principles, as well as interest in new residential districts in Sweden (Vällingby 1949-58, Farsta 1953-61) and Finland (Tapiola, first phase 1952-56), were transmitted through Moscow (Ojari 2000, 53-54). The International Union of Architects' (UIA) congress on the construction and reconstruction of cities, organised in Moscow in 1958 was of primary importance. This was used by Khrushchëv to proclaim the principles of 'open planning' and mikrorayons (Glendinning 2016, 633; Ojari 2000). These principles were also introduced as requirements in the planning competition for Mustamäe, held the same year. The Soviet 'calculative rationality' reduced the British idea of varied housing typology significantly: $80 \%$ of all housing units were to apply the 1-317 standard as 4-5 floor apartment blocks, which were the most economical to produce. The novelty of open planning principles was reflected in unsatisfactory competition entries (Ojari 2000, 55-59). Consequently, the local Design Institute Eesti Projekt was assigned to work on the 


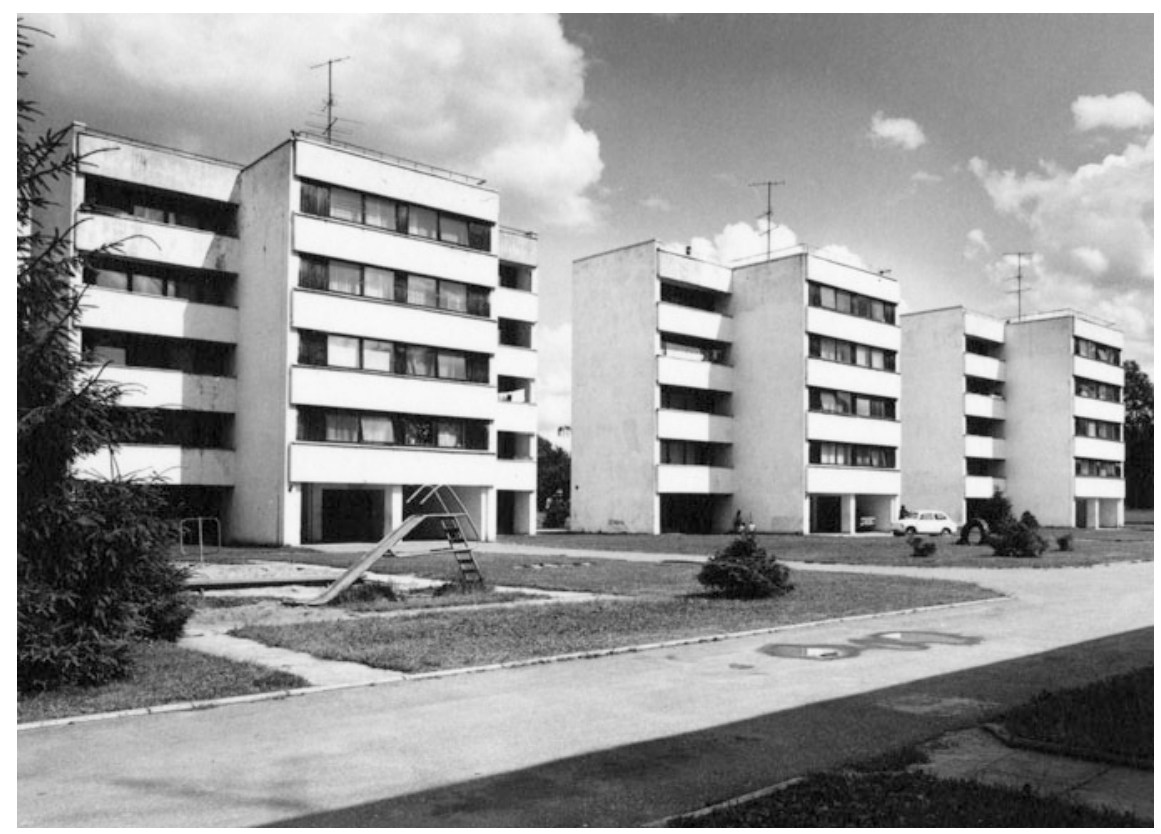

Fig. 5.4 Apartment blocks for the Estonian Academy of Sciences employees in Trummi Street, Tallinn (Raine Karp 1969-71) represent individually designed housing. Source Museum of Estonian Architecture, used with permission

Mustamäe plan. The planning team consisted of architects Voldemar Tippel, Toivo Kallas and Lidia Pettai, and engineer Aleksander Prahm, with whom Tippel had also participated in the Moscow conference and who were awarded the shared second place in the competition. According to Ojari (ibid. 59), the Western influence was recognised in the project, but the planners also took some distance to underline Soviet ideology. Before the construction started in 1962, the 1-464 precast buildings replaced the 1-317 standard in Mustamäe.

The use of standardised models significantly limited the possibilities to apply Nordic ideas. However, the Swedish and Finnish influences have been identified in Mustamäe's shopping and service centres (Lankots and Sooväli 2008), which were buildings that were developed as separate projects and in which architects had more freedom. In particular, Raine Karp's unrealised Mustamäe civic centre project (1964, 1972) bore a resemblance to Tapiola centre (Kalm 2002a, 346). Moreover, the Mustamäe V mikrorayon's commercial centre (Peep Jänes 1963-70) is a prime example of Finnish-inspired 'cornice architecture'. Indeed, Kalm (2002a, 368) argues that it was developed on the basis of Finnish suburban shopping centres. 


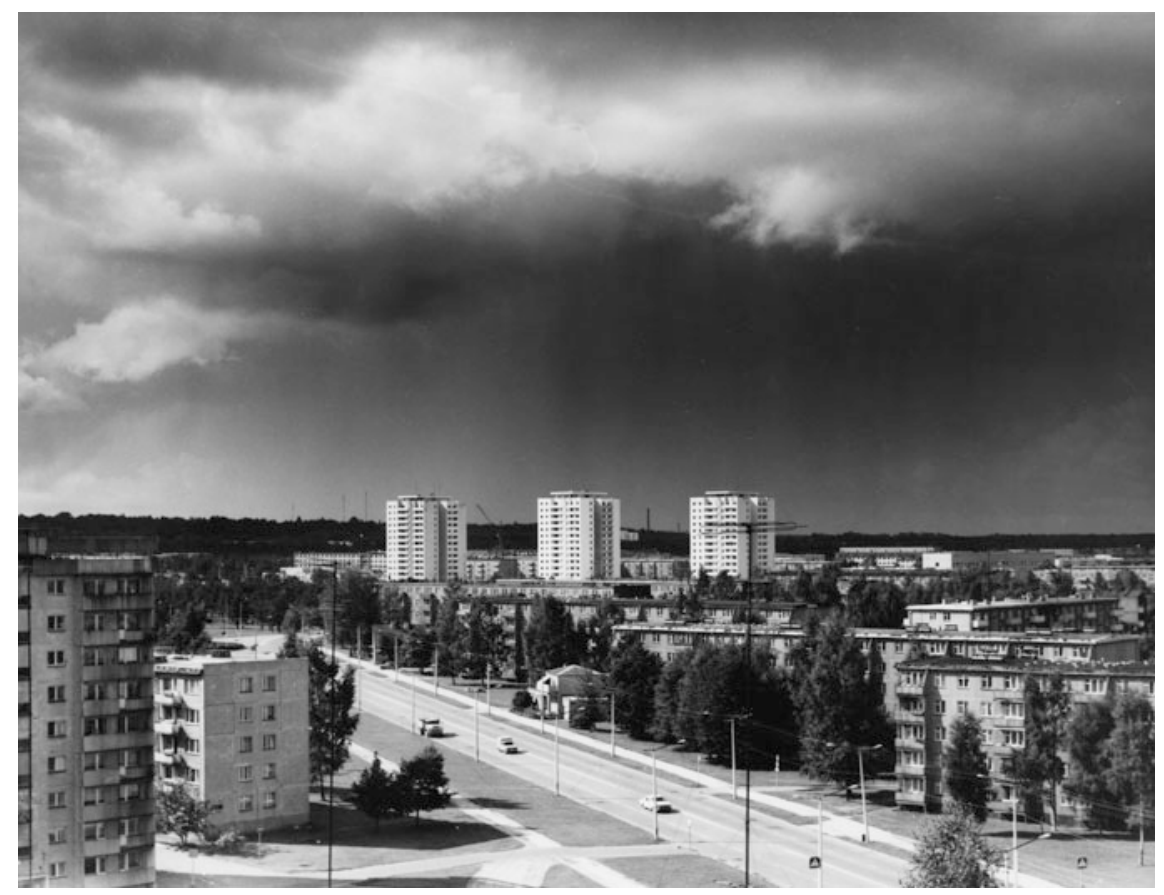

Fig. 5.5 The first mikrorayons of Mustamäe estate in Tallinn (1958-73) consist of 4- to 5-floor apartment blocks built with 1-464 standard. Source Museum of Estonian Architecture, used with permission

\subsection{Discussion and Conclusion}

The main question in this chapter was how Finnish architecture and planning influenced the development of multifamily housing, including large housing estates, in Soviet Estonia. To answer this question, we have provided an account of the ways in which architectural and planning information was transferred between the countries, what was of interest especially to Estonians, and what kind of influence it potentially had in developing multifamily housing in Soviet Estonia.

The connection between Finland and Estonia was restored in the late 1950s as a part of the Khrushchëv Thaw. Finland was one of the model countries to which the Soviet Union paid attention in terms of new town planning ideas (Ward 2012, 510). The difference between Finland and a number of other Western countries, such as the UK (Ward 2012), was that the connections did not fade as the Soviet Union's progressivity transformed into the conservatism of the Brezhnev era. To the contrary, the restoration of a direct passenger ferry connection between Helsinki and Tallinn in 1965 marked a steady flow of Finns to Tallinn. One reason was the collaborative policy of friendship between Finland and the Soviet Union, 
which allowed for cooperation to a certain extent, regardless of the different political and economic systems.

Information was exchanged most importantly through travel, professional publications and architecture exhibitions. Personal contacts played a pivotal role for several reasons. As meticulously monitored Soviet citizens, Estonians needed an acceptable reason to travel, which required contacts and an institutional invitation letter. The Finnish architects travelling to Estonia, for whom the journey was easy to make, were able to bring useful and inspiring materials, which were otherwise scarce in the Soviet Union. Finnish and other Western projects were also known through international journals and books, available in a few professional libraries, and through relatively rare exhibitions.

According to the architecture historians Hallas-Murula (2006) and Kalm (2002a), Estonians took a strong interest in Finnish modernism of the 1950s and the 1960s. The idea of carefully placing modern buildings in the natural surroundings was often perceived to be particularly Finnish, as were some stylistic details of the era. Professional publications and exhibitions enforced these interpretations. At the time, modernist residential projects were associated with progress and hope practically all over the world. Notably, Kalm (2002a, 326) has interpreted that Finnish modern architecture helped Estonians to re-establish their own architectural identity, distinct from other Soviet republics. Simultaneously, Estonians looked back to the country's own functionalist architecture from the interwar period, which created the neo-functionalist tendency in the 1970s.

In terms of residential areas, the most important Finnish references have been the Tapiola and Pihlajamäki districts in the Helsinki metropolitan area, both representing early Finnish housing estates located in natural surroundings, the forest-suburbs. In particular, Tapiola was visited and referenced by Estonian architects even decades after its completion. The travel reports written on the basis of the excursions were, however, often accompanied by pessimism that similar solutions or quality could not be transferred to the context of Soviet Estonia, at least not in housing estates.

In the mid-1960s, the planning paradigm changed internationally towards large and dense housing estates, referred to in Finland with the term 'compact city'. Finnish examples, such as Myyrmäki, Matinkylä and Hervanta, do not seem to have raised interest among Estonians. They rather continued to look back to buildings and estates that were no longer the most topical in Finland. Internationally, the progressive ideals of the 1950 s, associated with mass housing, also started to fade, and during the 1960s the question of production quantities was emphasised. Intriguingly, by looking at aerial photos, the differences between the spatial pattern and architecture of 1970s housing estates in Finland and those in Estonia are less striking than one might presume. Nonetheless, major differences persisted in building quality, landscaping, service provision and post-construction maintenance. Moreover, in Finland, monotonous large housing estates received grave public criticism, and the development gradually turned towards more varied housing areas in the late 1970s. In Estonia, the product of the Soviet housing construction machine did not change much up to the end of the Soviet period. 
To return to the main question of how Finnish architecture and planning influenced Soviet Estonian multifamily housing and housing estates, the answer is that it did so selectively, but only in housing projects in which architecture mattered. The common feature of such projects was that they were individually designed and constructed, in contrast to state-led mass housing. In the case of multifamily houses, these were commissioned by housing cooperatives, the collective farm construction companies (KEK), or equivalent independently operating state agencies. Such projects allowed for more flexibility and room for individual architects to express their ambitions. In terms of the large housing estates, this was possible only in smaller structures, such as the shopping and service centres, the centres of collective life in the mikrorayons. As this chapter has shown, this situation was not caused by a lack of inspiration, information or skills. It was the harsh logic of the Soviet housing production machine, dictated by advancements in mass construction technology. The prefabrication systems, sadly, had a greater role in transforming the built environment than the architects and their visions.

\section{References}

Anderson R (2015) Russia: modern architectures in history. Reaktion Books, London

Bater J (1980) The soviet City. Edward Arnold, London

Beyer E (2012) The Soviet Union is an enormous construction site. In: Ritter K, et al. (eds) Soviet modernism 1955-1991. Unknown history. Park Books, Zurich, pp 257-271

Bruns D (1961) Tapiola. In: Eesti NSV Arhitektuur, artiklite kogumik. Tallinn, pp 46-50

Caldenby C, Wolodarski A (1973) Byggande i Sovjetunionen. Statens institut för byggnadsforskning

Čeferin P (2006) Branded: the museum of Finnish architecture and the international promotion of Finnish architecture. In: Blomstedt $\mathrm{S}$ et al (eds) Suomen rakennustaiteen museo/Finlands arkitekturmuseum/Museum of Finnish Architecture 1956-2006. Helsinki, The Museum of Finnish Architecture, pp 38-54

Forsberg T, Pesu M (2016) The 'finlandisation' of Finland: the ideal type, the historical model, and the lessons learnt. Dipl Statecraft 27(3):473-495

Forty A (2012) Concrete and culture: a material history. Reaktion Books, London

Glendinning M (2016) Cold-war conciliation: international architectural congresses in the late 1950s and early 1960s. J Arch 21(4):630-650

Hall S, Murie A, Knorr-Siedow T (2006) Large housing estates in their historical context. In: Kempen Van et al (eds) Restructuring large housing estates in Europe. The Policy Press, Bristol, pp 63-84

Hallas-Murula K (2006) Suomi-Viro: Arkkitehtuurin yhteinen vuosisata. Viron Arkkitehtuurimuseo, Tallinna

Hankonen J (1994) Lähiöt ja tehokkuuden yhteiskunta. Otatieto Oy, Gaudeamus

Hannula P, Salonen M (2007) Rakennukset kertovat - perustietoa asukkaille. Helsingin kaupunginosayhdistysten liitto ry, Helsinki

Herkel V (1967) Soome väikeelamus. Ehitus ja arhitektuur 1/1967, 48-51

Høyer S, Lauk E, Vihalemm P (eds) (1993) Towards a civic society: the Baltic media's long road to freedom. Baltic Association for Media Research/Nota Baltica Ltd., Tartu

Hurme R (1991) Suomalainen lähiö Tapiolasta Pihlajamäkeen. Suomen tiedeseura, Helsinki

Hytönen Y, Seppänen M (2009) Tehdään elementeistä: suomalaisen betonielementtirakentamisen historia. SBK-Säätiö \& Betonitieto Oy, Jyväskylä 
Jürisoo U, Malmet J (1966) Ehitusalastest ekskursioonidest Soome. Ehitus ja arhitektuur 1/1966, 26-33

Kalm M (2002a) Eesti 20. sajandi arhitektuur/Estonian 20th century architecture. Sild, Tallinn

Kalm M (2002b) Sauna-party at the summer cottage: Soviet Estonians play at being Western. In: Korvenmaa P, Laaksonen E (eds) Universal versus Individual: The architecture of the 1960's. Alvar Aalto Academy, Jyväskylä, pp 53-75

Kalm M (2004) Kolm nuppu ja lint: Helsingi Pihlajamäelt Tallinna Trummi tänavale. Maja 1-2 (2004):57-62

Kalm M (2007) The oasis of the industrialised countryside in Soviet Estonia. In: Kervanto Nevanlinna A (ed) Industry and modernism. Companies, architecture, and identity in the Nordic and Baltic Countries during the high-industrial period. Finnish Literature Society, Helsinki, pp 352-371

Kalm M (2012a) 'An apartment with all conveniences' was no panacea. Mass housing and the alternatives in the Soviet Period in Tallinn. Arch Urban J Arch Town-Plan Theory 47:189-202

Kalm M (2012b) Baltic modernism. In: Ritter K et al (eds) Soviet modernism 1955-1991. Unknown history. Park Books, Zurich, pp 32-45

Kivi RL (1960) Arhitekti muljeid Soomest. Kunst ja Kodu, nr. 3

Klotz H (1988) Paper architecture. New projects from the Soviet Union. Rizzoli, New York

Kotli A (1963) Tallinnan uusi laululava. Arkkitehti 1-2 (1963)

Kurg A (2009) Architects of the Tallinn School and the critique of Soviet modernism in Estonia. J Arch 14(1):85-108

Lahti J (2006) Arkkitehti Aarne Ervin moderni. Kaupunkisuunnittelu pääkaupunkiseudulla. Taidehistoriallisia tutkimuksia 34. Helsinki

Lankots E, Sooväli H (2008) ABC-keskused ja Mustamäe mikrorajoonide identiteetid. Kunstiteaduslikke Uurimusi/Stud Art Arch 17(4):88-109

Lapin L (1980) Funktionalismi Eestin uudessa arkkitehtuurissa. Arkkitehti 3(1980):53-58

Lapin L (1996) Pimeydestä Valoon. Viron taiteen avantgarde neuvostomiehityksen aikana. Otava, Helsinki

Luts K, Avarsoo E (1967) Soome haiglatest. Ehitus ja arhitektuur 4(1967):24-29

Metspalu P, Hess DB (2018) Revisiting the role of architects in planning large-scale housing in the USSR: The birth of three large housing estates in Tallinn, Estonia. Plan Perspect 33(3):335361. https://doi.org/10.1080/02665433.2017.1348974

Meurman O-I (1947) Asemakaavaoppi. Otava, Helsinki

Meuser P (2012) Serial housing construction in the Soviet Union: an architectural-historical approach. In: Ritter K et al (eds) Soviet modernism 1955-1991. Unknown history. Park Books, Zurich, pp 273-283

Meuser P, Zadorin D (2015) Towards a typology of Soviet mass housing. Prefabrication in the USSR 1955-1991. DOM Publishers, Berlin

Mirov B (1965) Arhitekti tähelepanekuid Soome reisilt. Ehitus ja arhitektuur 1(1965):41-43

Mumford E (2000) The CIAM discourse on urbanism, 1928-1960. The MIT Press, Cambridge and London

Neuvostoliiton nykyarkkitehtuuria (1973) (Exhibition catalogue). Neuvostoliiton arkkitehtiliitto and Suomen rakennustaiteen museo

Ojari T (2000) Modernismi parameetrid: Mustamäe kujunemisest. Kümme. Eesti Arhitektuurimuuseumi Aastaraamat. Eesti Arhitektuurimuuseum, Tallinn, pp 49-64

Ojari T (2004a) Elamispind. Modernistlik elamuehitusideoloogia ja Mustamäe/Floor space. The modernist residential housing ideology and Mustamäe. Kunstiteaduslikke Uurimusi/Stud Art Arch 13(2):42-65

Ojari T (2004b) Soome märgid Nõukogude ajas. Maja 1-2(2004):22-27

Pedak K (1999) Eesti-Soome suhetest ja pisut ka arhitektuurist. In: Karu K (ed) EAL 1921-1996: fragmente Eesti arhitektuurelust. Solnessi Arhitektuurkirjastuse OÜ, pp 90-91

Ritter K, Shapiro-Obermair E, Steiner D, Wachter A (eds) (2012) Soviet modernism 1955-1991. Unknown history. Park Books, Zurich 
Ruoppila S (2004) Processes of residential differentiation in socialist cities. Literature review on the cases of Budapest, Prague, Tallinn and Warsaw. Eur J Spat Dev, refereed article no 9, $24 \mathrm{pp}$.

Smith MB (2009) Khrushchëv's promise to eliminate the urban housing shortage. In: Ilic M, Smith J (eds) Soviet state and society under Nikita Khrushchëv. Routledge, Oxon, pp 26-45 von Hertzen H (1946) Koti vaiko kasarmi lapsillemme. WSOY, Porvoo

Ward SV (2012) Soviet communism and the British planning movement: rational learning or utopian imagining? Plan Persp 27(4):499-524

Wassenberg F, Turkington R, van Kempen R (2004) High-rise housing estates in Europe. In: Turkington et al (eds) High-rise housing in Europe. DUP Science, Delft, pp 1-14

Open Access This chapter is licensed under the terms of the Creative Commons Attribution 4.0 International License (http://creativecommons.org/licenses/by/4.0/), which permits use, sharing, adaptation, distribution and reproduction in any medium or format, as long as you give appropriate credit to the original author(s) and the source, provide a link to the Creative Commons license and indicate if changes were made.

The images or other third party material in this chapter are included in the chapter's Creative Commons license, unless indicated otherwise in a credit line to the material. If material is not included in the chapter's Creative Commons license and your intended use is not permitted by statutory regulation or exceeds the permitted use, you will need to obtain permission directly from the copyright holder.

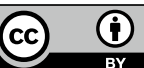

